\title{
CHALLENGES TO MULTINATIONAL COMPANIES AND ITS IMPACT ON THE MARKETING POLICIES IN EGYPT
}

\author{
Ahmed Eid GHAREEB ${ }^{1}$
}

Received Date (Başvuru Tarihi): 30/03/2017

Accepted Date (Kabul Tarihi): 16/05/2017

Published Date (Yayın Tarihi): 03/06/2017

\section{ABSTRACT}

Although many studies discussed Marketing Mix from different areas like (P. Yasanallah, et al ,2012; Thomas, 2010; Gandolfo, et al. 2009) but no one discussed it's relation with the political changes so this paper aims to investigate the challenges to multinational companies and its impact on the marketing Mix after Egyptian Revolution. In order to do so, The researcher investigated a field study taking a sample participants of 110 managers and specialists from the studied companies and gave them a questionnaire about the Challenges to multinational companies. It was found a positive and statistically significant relationship between Challenges to multinational companies and its impact on the marketing Mix. So multinational companies should change marketing policies according to political, Economic and Legal changes and the regime in every country they invest in.

\section{ÇOKULUSLU ŞİRKETLERINN KARŞILAŞTIKLARI ZORLUKLAR VE BU ZORLUKLARIN MISIR'DAKI PAZARLAMA POLITIKALARINA ETKISİ}

ÖZ

Pazarlama karması ile ilgili farklı alanlarda pek çok çalışma yapılması na rağmen, (P. Yasanallah ,v.d., 2012; Thomas, 2010; Gandolfo, v.d.. ,2009) hiç kimse pazarlama karmasının siyasi değişimlerle olan ilişkisini incelememiştir. Bu çalışmanın amacı çokuluslu şirketlerin karşılaştıkları zorluklar ve bu zorlukların Mısır Devriminden sonra pazarlama karmasına olan etkilerini araştırmaktır. Bu araştırmanın yapılabilmesi için incelenen şirketten 110 yönetici ve uzmanın katıldı ̆̆ bir saha çalışması yapılmış ve katılımcılara çokuluslu şirketlerin karşılaştıkları zorluklar ile ilgili bir anket uygulanmıştır. Çokuluslu şirketlerin karşılaştıkları zorluklar ve bu zorlukların pazarlama karmasına olan etkileri arasında olumlu ve istatistiki olarak önemli birilişki b ulunduğ $u$ görülmüştür. Sonuç olarak, çokuluslu şirketler pazarlama stratejilerini yatırım yaptıkları her ülkedeki siyasi, ekonomik, yasal değişikliklere ve rejime göre değiştirmelidir.

\footnotetext{
1 Jazan University, Community college, 42145, Jazan, Saudi Arabia, phone: 00966557619459, Fax: (+966)73235398 , E-mail: theprof82@yahoo.com Ahmedeid82@jcba.edu.sa
} 


\section{CHALLENGES TO MULTINATIONAL COMPANIES AND ITS IMPACT ON THE MARKETING POLICIES IN EGYPT}

The world is seeking for changing quickly and many organizations find it difficult to pursue this change and understand the origins of the game of international competition. Many organizations are seeking to survive and stay in the field by drawing effective strategies, which fit with the global changes and international challenges.

Globalization, the macro-level gradual integration and growing interdependence of national economies, driven by the reduction and elimination of trade barriers, increased trade, travel, and technological innovations, has facilitated and compelled firms to internationalize many value chain activities. Cavusgil et. al.(2008)

As the world witnessed a series of political challenges, social and economic, in light of the new global economic conditions, especially the emergence of the Arab revolutions, the division of Sudan, the global financial crisis, economic blocs, international competition, the spread of multinational corporations, the new roles of international organizations.

All of this led to the increasing of the attention of the need for marketing in general, and international marketing, in particular, and oincreasing the need for marketing information in an effort to invade the international markets, and this of course after the development of companies products and activate the marketing functions to ensure the flow of goods and services to home and abroad.

And through the development and continued progress in the various business activities , industrial activities, services activities, and especially technological activities, competitive advantages could be measured by the extent of the ability of creativity and innovation and renewal, which is consistent at the same time with the requirements of foreign markets, opening broad areas for growth for institutions and opening many markets and that is because the greatest importance of international marketing, which is considered an indicator of the organization's success in entering global markets. Consequently, the institutions which have developed marketing activities can compete efficiently and effectively in markets, and that is reflected in the great success of the institutions of developed countries such as American institutions, German institutions, and Japanese institutions...etc.

Increasing environmental challenges have critically changed the way we do and perceive the business. Challenges like rapid change, the rise of internet, workforce diversity, globalization, changing legislation, evolving work and family roles, skill shortages, and the rise of service sector have not only impacted the organizational structures but also changed the nature and role of every business functionality. (Gomez-Mejia et al, 2001).

The economic justification for the presence of any organization whatever was its goal is its survival and growth in the market. This depends mainly on its ability of Marketing in the markets that serve it, regardless of whether marketing is locally or internationally, whereas international marketing is an opportunity for many institutions for growth and expansion by working within it, as the international marketing is considered broad and complex. 
Planning is important because of the instability, or the rapid and continued change of environment in which the organization operates. Some examples of change are The issuance of new laws, the new changes that occur in the economy, and the changes that occur in the needs and desires of consumers. These changes are out of the control of marketing manager and at the same time have a significant impact on the success or the failure of the organization.

And the international marketing environment means all the variables and elements which effect on the marketing decision-making process in the different working circumstances between different countries and different states. The international marketing environment characterized in general by the phenomenon of movement and free exchange of goods, services, capital, values, cultures and other things.

Although there are a lot of marketing variables but marketing decision-making focuses primarily on four key strategies which can be called The Marketing Mix. These variables are production, pricing, promotion, distribution.

The International marketing mix has the ability to compromise and deal with the special variables of the marketing activity. The elements of the international marketing mix are the same elements of local marketing, but the design of these elements is linked to global markets, as an attempt to harmonize with global demand for products. The elements of the international marketing mix must be characterized by continuity because of the dynamic nature in which international marketing activity operates, so it must be re-examined from time to time, depending on the factors and changes of the international marketing environment.

\section{THE IMPORTANCE OF THE RESEARCH}

This can be illustrated by the importance of the research at the academic level and practical level, in the following manner:

\section{A - At The Academic Level:}

The marketing management occupies a prominent place in the organizational structure of international companies, that's due to their growing need for doing studies and market analysis, also for having knowledge of the reactions of consumers, customers and competitors. The interest of marketing management increases when the institution become larger, its production increases, and its market expands. Some institutions supervise on organizing and monitoring its sales by itself or assign the distribution process to specialized institutions. The choice of these methods depends on several factors including the institution's financial ability, organizational ability production volume and variety, and the size of customer numbers, etc.

This research is important at the academic level as it studies the problems and constraints of marketing management on the international level and provides appropriate solutions for it through:

A.1. Estimate the strategic place for the role of the consumer and its association with the survival of the company, growth, and stability. 
A.2. Build a good reputation at the local level, and at the international level of the company.

A.3. Contribute to the promotion of production on a large scale, which creates a large abundance.

A.4. Identify the impact of free trade zones on the movement of markets and exports. marketing.

A.5. Identify the impact of economic blocs on the future of the movement of global

\section{B- At The Practical Level:}

The global developments Led to transforming the field of Business Administration in order to become the administration of international business, where the global media, the Internet, means of developed communication in addition to electronic commerce and the global road network led to turn the continents and countries into one global community, which affect the local and global shopping that can be clear through:

B.1. Marketing management gives great interest in creating products that are designed in the light of a specific role to solve some of the purchasing problems of consumers.

B.2. Exporting is a good way to get hard currency which countries need to import products that can't be produced locally, and thus it is considered a good national gain which leads to rising the standard of living and development and raising the purchasing power of consumers.

B.3. International Marketing allows the sale of the surplus of the institution abroad and creates opportunities for employment, it is an especially vital necessity.

B.4. Developing countries take benefits from the direct foreign investigations economically and socially and politically, even though the investing countries in developing countries do so only for their advantages.

B.5. Supporting of the wheel of development, because the international marketing needs many skills, and is subject to a number of other considerations

B.6. Achieving the possibility of Contacting with the global stock markets.

B.7. Achieving the ability to study and analyze markets and respond to the needs of the global consumer.

B.8. Contacting with international markets, using all technical means available in foreign markets.

B.9. Planning and developing desired and needed products by consumer or investor in foreign markets. 


\section{THE INTERNATIONAL CHALLENGES FACED BY MULTINATIONAL COMPANIES}

\section{A. Marketing Policies}

A new concept has Appeared in the marketing science that was not found before, which is presented as the social networking (Facebook, YouTube, Twitter IPhone, I pad ) and it has become the language of understanding, dealing and communicating with people in various fields, whether it was political, economic, legal, social or cultural, which led to the reshaping of relations between states, people and governors as it is being used in election campaigns, the Arab revolutions, in the political environment, in the legislation of the legal environment, product promotion and delivery of the markets, whether local, regional or international economic environment . so the multinational companies are affected by sales, earnings growth, expansion and marketing policies etc....

Therefore, the practice of the multinational companies for their activities in various countries around the world makes the process of marketing decision-making very important and has a pivotal role in the success or failure of these organizations. Since, the rapid environmental changes, whether it was technological, political, legal, social or economic need decisions which reflect the pattern of the Organization's response to these changes. Thus planning for the local market differs from planning for the international markets and this is due to the following factors:

A.1, The different nature of the business environment, which every kind of planning deals with, as well as the different environment between different countries and the different degree of progress and growth of industry structure, competition, laws, conventions and economic conditions and the concept of market's rule, all of these leads to the variety of planning tools and multiple alternatives and strategic choices according to the multiplicity of the business environment.

A.2, The different methods of implementation of the strategies that are selected from state to state, for example, the implementation of the marketing strategy for the same product differs from a country to another depending on the state which the product is marketed in, as a result of the different values, beliefs, and rules that govern the market.

A.3, Strategic plans for the international economy varies and complicates as a result of the enormous challenges and problems of the different cultures and degree of risk, where these strategies depend on a unique competitive advantage. So the organization's success depends on the full understanding of the features of competitive and comparative advantages, such as the advantage of lower costs in a country or a particular location as a result of the availability of skilled workers or raw materials or markets. This advantage can be found on technology processes that the organization depends on or can be found on administrative practices and thus the organization succeeds in achieving growing.

The international marketing is associated with many other external activities, for example, international marketing is linked to the external environment which includes many factors and variables of economic, social, cultural, political, etc. The international marketing is 
linked to foreign markets where there are consumers with a multiple and diverse cultures that often influence the behavior of consumers in those markets. International marketing associated with the methods of promotion, distribution, and pricing which vary according to the nature of systems, laws, and regulations in foreign markets. The international marketing is also linked to the external customer who resides in foreign markets differs from the internal market in the characteristics, trends, and needs. As in figure (1) Environmental Analysis Framework (EAF)

During the Cold War, Muslims were cultivated as allies and partners on many fronts, such as the Mujahedeen in Afghanistan. At the time, Ronald Reagan lauded them as 'the moral equivalent of our founding fathers'. When the Cold War ended these allies were dropped. Samuel Huntington's 'clash of civilizations' article in 1993 signaled a major turn by targeting the Islamic world (in fact, the Confucian-Islamic alliance with specific reference to the cooperation between China and Pakistan). Erstwhile allies and partners were redefined as enemies; yesterday's freedom fighters became, literally, today's terrorists. In response to this policy shift and continuing Israeli and American politics of tension and aggression in the Middle East followed a Muslim backlash, of which $9 / 11$ is a part. The Cold War 'arc of crisis' has become an 'arc of extremism' with flashpoints in the Middle East and Central Asia. Satellite TV channels in the Arab world contribute to awareness among Muslims. Muslim organizations increasingly demonstrate high militancy and swift responses, for instance to the Danish cartoons and statements by Pope Benedict. The Lebanon war in 2006 has shown Israel's weakness and Hezbollah's strength as part of a regional realignment away from the American-supported Sunni governments to Iran, Syria, and Shiites. The US siding with Israel's stance in the region contributes to its self-isolation. James,(2004).

The "multinational process" implies that the international marketing process is not a mere repetition of using identical strategies abroad. The four Ps of marketing (product, place, promotion, and price) must be integrated and coordinated across countries in order to bring about the most effective marketing mix. In some cases, the mix may have to be adjusted for a particular market for better impact. Coca-Cola's German and Turkish divisions, for example, have experimented with berry-flavored Fanta and a pear-flavored drink respectively. In other cases, a multinational marketer may find it more desirable to use a certain degree of standardization if the existing market differences are somewhat artificial and can be overcome. As in the case of General Electric Co.'s GE Medical Systems, it went too far in localizing its medical imaging products to compete with local competitors. Its managers designed and marketed similar products for different markets. Over customizing such big-ticket products is an expensive and wasteful duplication of effort. The World, Erase Its Border," Business (2000, 113-114)

\section{B. Environmental Analysis Framework:}

Figure (2): The marketing environment can clearly show the Environmental components. Which could be illustrated as follows:

\section{B.1. Political environment:}

Political factors can influence marketing decisions by determining the rules by which business can be conducted. The relationship between government and business organizations can have major implications not only for the respective parties but also other companies (Jobber 2004: 146) 
Furthermore, for the foreign company entering into a new market, the laws, rules, and regulations need to be understood before the entry, because Businesses to-day need to follow both official regulations and also regulations pressed by special-interest groups. However, in some cases, companies can even benefit from the newly established laws (Kotler 2000: 151). A product related to public safety, such as bicycle helmet, can be made mandatory for all citizens in which case the manufacturer of this product naturally benefits.

The poor political performance combined with high level of corruption led the government to collapse and created political instability.

President Abdel Fattah Al-Sisi continued to wield both executive and legislative powers in 2015, with no elected legislature in place since the July 2013 coup against then president Mohamed Morsi, which also dissolved the parliament. The new, overwhelmingly government parliament was scheduled to hold its first session in early 2016.

Journalists frequently face interference in the course of their work. Domestic media rights organizations documented numerous cases of obstruction of coverage, illegal detention, and outright attacks in 2015, and the rate of violations spiked in the last quarter of the year, during and after parliamentary elections. Many such incidents also took place during January 2015 demonstrations marking the fourth anniversary of former president Hosni Mubarak's ouster; numerous journalists were assaulted, detained, or had their equipment confiscated while covering the events. The Association for Free Thought and Expression (AFTE), an Egyptian NGO, documented dozens of physical attacks against journalists in 2015, committed by both security forces and civilians. Journalists have been detained for long periods of time without charge, and some have reported torture or other mistreatment in custody. According to an August 2015 Amnesty International report, Mahmoud Abu Zeid, a freelance photojournalist who has been held in pretrial detention since August 2013, said he was tortured by security agents and has been denied medication necessary to treat hepatitis.

Authorities restricted reporting on security issues through a variety of means during 2015. Among them was a new counterterrorism law, issued by al-Sisi in August, that prohibits journalists from publishing information related to militant violence if it contradicts official government accounts. Violations can result in heavy fines and a one-year ban from the practice of journalism. The measure makes it extremely difficult for journalists to freely report on areas affected by terrorism and insurgency, particularly the Sinai Peninsula.

\section{B.2. Economic environment}

The economic environment can have a critical impact on the success of companies through its effect on supply and demand. Companies must choose those economic influences that are relevant to their business and monitor them. Three major economic influences should be examined on the marketing environment of companies: economic growth and unemployment, the development and implications of the single European market, and the economic changes that are accompanying the transition to market economies of eastern bloc countries (Jobber 2004: 132). The analysis of economic environment can let companies know the financial situation of the target country in order to forecast the potential market demand, the buying power and the foreign investment situation in the target market. 
As Egypt marks the fifth anniversary of the 2011 revolution on 25 January, it looks back on five years of rapid political change, social dislocation, and economic turmoil. How has Egypt's economy fared since 2011, and what is the outlook for the next five years? By numbers alone, on the eve of the revolution, Egypt's economy looked fairly healthy. During the mid2000s, growth in gross domestic product (GDP) averaged an impressive seven percent annually. In 2010, the country had accumulated foreign currency reserves equivalent to $\$ 35 \mathrm{bn}$ (sufficient to cover 8.6 months' worth of imports) according to the Central Bank of Egypt (CBE), and in the same year GDP per capita stood at $\$ 2,600$ according to World Bank indicators, an increase of almost 50 percent on $\$ 1,400$ in 2006 .

However, these headline figures masked the fact that the growth was not evenly shared. Much of it was consumption-led rather than investment-led and concentrated in capital-intensive fields like petrochemicals and energy that tended not to create many jobs. Combined with corruption and red tape, this resulted in a large informal economy - a 2014 study from the Egyptian Centre for Economic Studies put it at two-thirds the value of the formal economy. World Bank figures show that in 2010 poverty rates were running at about 25 percent, up from 16.7 percent in 1999. So while political and social exclusion may have been factors in causing the revolution, economic exclusion shouldn't be underestimated.

In the aftermath of the revolution, uncertainty over the final outcome led to economic contraction and sluggish growth. Over the past five years, Egypt has shifted through being governed by the Supreme Council of the Armed Forces (SCAF) to president Mohamed Morsi, who was in turn removed by SCAF, and now by Abdel Fattah Al-Sisi. The currency has depreciated and Egypt has required substantial infusions of funding from the international community after imposing capital controls in 2011.

The value of the Egyptian pound (LE) has fallen from 5.5 LE to the US dollar in January 2010 to 7.8 LE this January and substantially less on the black market. In November 2015, the CBE reported net reserves of $\$ 16.4 \mathrm{bn}$, or 3.4 months' worth of imports. As a rough measure of international confidence in the Egyptian economy, World Bank indicators show foreign direct investment (FDI) inflows amounted to $\$ 4.8 \mathrm{bn}$ in 2014, slightly up from $\$ 4.2 \mathrm{bn}$ in 2013 , but far below the $\$ 11.6 \mathrm{bn}$ of 2007. Middle East Eye. We Could Illustrate some variables effected on Marketing Mix as a Following:

\section{Foreign Investment:}

Foreign investment in Egypt deteriorated after the revolution from 6.8 to 2 USD Billion for the fiscal year 2010/11. The main indices of Egypt's stock exchange (EGX 30 and EGX 100) both dropped by $10.5 \%$ and $14 \%$ after the revolution, (ECES, June 2011). As well as the growing deficit in the trade balance, which exceeded the 28 billion dollars in 2011, and the fall in foreign direct investment is less than 2 billion dollars after they had crossed the $\$ 113$ billion a few years ago (CBE, Annual report, 2011).

\section{- Debt crisis}

The debt represents $15.2 \%$ GDP; this indicator comes from the best global levels, which ranged from $15.3 \%$ for the developing Asian economies and $66.0 \%$ for North and Central European countries. Moreover, the indicator of debt service/exports of goods and services recorded $5.7 \%$, i.e. less than the global levels forecast for 2011 that ranged between $11.0 \%$ for 
Sub-Saharan Africa and $55.8 \%$ for North and Central Europe, according to the IMF ${ }^{\text {ee }}$ World Economic Outlook (IMFees World Economic Outlook - Sept. 2011).

- $\quad$ Balance of Payments and External Trade

There are two basic factors that contributed to the overall deficit: the current account deficit which retreated by 35.9 percent to a record US\$ 2.8 billion (against US\$ 4.3 billion a year earlier), and the capital and financial account that unfolded a net outflow of US\$ 4.8 billion (against a net inflow of US\$ 8.3 billion).

- Unemployment

Egypt's unemployment rate in the last quarter of 2010 was 9.5 percent; it has risen to 11.9 percent in the first quarter under the impact of the political unrest (CAMPAS, 2011). The World Factbook estimated a 3.2\% increase in the unemployment rate in Egypt to currently be at a level of $12.2 \%$ instead of $9 \%$ just a year ago; this shows the shocking effect that the Arab Spring has had on Egypt's unemployment rate (Hagen, 2011). HAGEN, E. 2011. Egypt Not A Refugee Heaven. Ahram Online. Available on: http://english.ahram.org.eg/News/14661

Unemployment at 12.5 percent in mid-2016 (up from 9 percent prior to 2011) is a particular concern, with higher rates among the youth and women. Furthermore, recent increases in the population growth rate is placing additional pressure on infrastructure and services. This is creating additional impetus for reforms to generate economic growth and to respond to the needs of the population and their expectations of improvements in well-being.

\section{B.3. Social and cultural environment}

The population in developed economies is expected to be stable or shrinking. A major demographic change that will continue to affect the demand for products and services is the rising proportion of people over the age of 45 in the EU, and the decline in the younger age group. Moreover, within Europe, cultural differences have implications for the way in which business is conducted which need to be recognized when interacting with European customers (Jobber 2004: 138, 141).

Furthermore, understanding of the social and cultural factors is also the way to know the customer needs for companies. If companies know more the consumer's life standard and their characteristics, it is more convenient to make decisions on the customizing products.

\section{B.4. Technological environment}

Technology can have a substantial impact on people's lives and companies' fortunes. Monitoring the technological environment may result in the spotting of opportunities and major investments in new areas (Jobber 2004: 152). The key to successful technological investment is market potential and technological change can also pose threats to those companies that gradually find they cannot compete effectively with their more advanced rivals.

\section{B.5. Legal environment}

Egypt was under a state of emergency from 1981 until May 2012, and for three months following The 2013 Coup. The Emergency Law grants the government extensive powers of 
surveillance and detention. A state of emergency and nighttime curfew have been in place since October 2014 in Northern Sinai, with repeated three-month extensions. A decree extending the measures in July 2015 followed coordinated attacks by the region's IS affiliate that killed dozens of soldiers. Freedom of movement and property rights were severely affected by the government's counterinsurgency efforts in the Sinai in 2015. In addition to the curfew, checkpoints, and other travel restrictions, the military has summarily demolished buildings in the town of Rafah to create a buffer zone along the border with the Gaza Strip, displacing thousands of families and destroying over 3,000 homes and other structures as of late 2015. Authorities also pumped seawater into smuggling tunnels in the area, raising health and environmental concerns.

The authorities continued to arrest and prosecute journalists during 2015, subjecting them to deeply flawed legal proceedings that disregarded their fundamental rights. According to CPJ, 23 journalists were behind bars in Egypt as of December, with the number reaching 36 at its highest point during the year. In April, 13 journalists were sentenced to life in prison, and one was sentenced to death, following convictions for plotting against the state during a 2013 sit-in at Cairo's Raba'a Square, which ended when a violent crackdown by security forces killed hundreds of civilians. After months of delays and obstructions in the appeals process, Egypt's Court of Cassation granted the journalists a retrial in December, though they remained in custody. In January 2015, an appeals court granted a retrial to three employees of Qatar's AlJazeera television network who were detained in late 2013 and subsequently sentenced to lengthy prison terms for supposedly spreading false news and aiding the Muslim Brotherhood, now deemed a terrorist organization. One of the reporters, Peter Greste, an Australian citizen, was deported in February 2015. The others-Mohamed Fadel Fahmy, an Egyptian-born Canadian citizen, and Baher Mohamed, an Egyptian national-were released on bail later that month but convicted again at their retrial in August, along with Greste in absentia. In September, Fahmy and Mohamed were released under a presidential pardon. A number of other journalists faced the imminent threat of detention in connection with pending charges or convictions in absentia.

- Egypt was the world's second-worst jailer of journalists in 2015 , according to the Committee to Protect Journalists (CPJ), with 23 reporters behind bars as of December.

- A new counterterrorism law banned the dissemination of material that contradicts Defense Ministry accounts of militant attacks, severely curtailing journalists' ability to report on national security topics.

- The already high rate of media freedom violations spiked during the parliamentary election period, which lasted from October through early December.

- The struggling public broadcaster continued to lose viewership during the year, as audiences turned to private channels based both in Egypt and abroad.

After mentioning the different kinds of environments and its effect on marketing policies you can see how environmental changes can affect the marketing policies from this illustration of the Egyptian environmental changes after the Egyptian revolution.

The reflection of The Egyptian revolution on Business Environment and Especially on Marketing Policies can be summarized as Follows:

- $\quad$ low foreign direct investments 
- $\quad$ a high budget deficit

- a high debt rate

- a high unemployment rate

- $\quad$ a high poverty rate

- a low standard of living.

- $\quad$ increase the inflation rate

- $\quad$ increased level of poverty

- $\quad$ increase level of food prices

- $\quad$ low revenues from exports

- The Egyptian foreign exchange reserves have been dropping rapidly, as they were \$36 billion pre-revolution and $\$ 15$ billion post-revolution.

- Egypt has lost around two billion U.S. dollars in tourism revenues due to this political unrest

- Tourism revenues dwindled by 47.5 percent in the second half of the year, compared with the first

- The tourism sector is one of the country's economic pillars; Egypt in 2010 had 14.7 million tourists, but after January 25 th tourism revenues dropped by 60 percent

Preliminary Egypt's data at end of September 2015 showed a decrease in total assets and total liabilities, compared to the position of end-June 2015, to achieve net liabilities of about US\$ 97.8 billion versus US\$ 93.6 billion. Egypt's total financial assets decreased by about US\$ 4.7 billion, to reach US\$ 42.8 billion in September 2015, down by 9.9 percent compared to June 2015. Meanwhile, total financial liabilities amounted to US\$ 140.6 billion, decreasing by about US\$ 0.5 billion or 0.4 percent, compared with June 2015. Central Bank of Egypt - External Position (External Position of the Egyptian Economy July/September 2015/16)

New era of monetary policy amidst foreign exchange shortages and high inflation The fiscal year 2016 saw several important milestones so far after a new Central Bank Governor assumed office in November 2015, introducing a shift from an accommodative monetary policy to a tight one amidst a stubbornly high inflation, easing capital controls and initiating new import rules in the aim of solving Egypt's chronic foreign exchange shortages. This came along pressures on the Central Bank of Egypt's gross official reserves despite GCC deposits. Inflation remains stubbornly high, largely due to supply bottlenecks and the Egyptian Pound depreciation. The Headline Consumer Price Index for urban areas rose by $11.0 \%$ on average in FY 2015 and by $9.6 \%$ on average during the first half of FY 2016.

Capital markets under downward price pressures amidst weaker investor sentiment across the region Egypt's capital markets followed a downward trajectory over the year 2015, mainly dragged by weaker investor sentiment across the MENA region, lingering local security and geopolitical concerns and speculation about an interest rate hike by the US Federal Reserve. 
Accordingly, the Egyptian Exchange price index of the 30 most highly capitalized and liquid stocks saw its first contraction in four years. The fixed income market registered sharp price declines that swept out the previous year's gains, and the cost of insuring debt expanded significantly. The bourse main benchmark index (EGX 30) tumbled by $21.5 \%$ in 2015 to close at $7,006.01$ at year-end. In parallel, Egyptian sovereign debt papers saw downward price movements in 2015, with Z-spreads widening significantly, tracking price falls across the region. Egypt's five-year CDS spreads, a reflection of market perception of country risks, widened significantly by 196 bps over the year to close at 478 bps at end-2015, following a notable contraction of $323 \mathrm{bps}$ in 2014.

Egypt's capital markets were at the image of regional tensions and the adverse effects of the drop in oil prices. Egypt's 5-year CDS spreads, a reflection of market perception of country risks, reported a 196 basis points expansion to reach 478 basis points. The Egyptian Stock Exchange saw a $27.5 \%$ drop in prices in 2015 , driven by weaker investor sentiment across the region, some adverse local security developments and lingering geopolitical concerns after the terrorist act that brought down the Russian passenger plane in Egypt on October 31, 2015. The latter according to Moody's would have credit negative implications for the country's balance of payments and pose downside risks to the country's outlook. These unfavorable market spillovers were partly offset by Saudi Arabia's pledge towards the end of 2015 to raise its investments in Egypt and to contribute to providing Egypt with petroleum needs for the next five years.(Egypt economic report February 24, 2016)

External Position of the Egyptian Economy July/September 2015/16

\section{SAMPLE AND SOCIETY OF THE RESEARCH}

Information was collected from respondents like marketing and sales managers in addition marketing and sales specialists We picked 110 managers and specialists from the studied companies to be our sample participants. we gave them a questionnaire which they answered during their break time in the field study which the researcher made after illustrating the questionnaire. The field work had taken almost ten days.

Research limits have been done in the evaluation of marketing policies of multinational companies in the Arab Republic of Egypt. The study targeted multinational companies operating in the Arab Republic of Egypt that work with exporting capital amounted to about 35 billion pounds and investment costs amounted to about (50) billion pounds, which have contributed to the provision of $(145,879)$ thousand jobs, according to the statistics of 2012 according to the report of the General Authority for Investment and Free Zones. also among the foreign companies operating in the industrial sector. There are (502) multinational companies. They represent (76.29) and the rest is completely foreign companies and shared companies for the rest. The researcher just confined to multinational companies operating in the industrial field without exposure to fully foreign companies or multinational companies in free zones.

As in table (1) Distribution of multinational industrial companies according to the type of industry, it is clear that a number of multinational companies operating in the industrial field have numbered about 175 to 2012 with investment costs exceeded 11 billion pounds, and because of the costs of investment, covered by companies operating in the food industry, which 
amounted ( 2782 million ). The researcher focused on studying the field of food Industries. The study was limited to choose this field, in accordance with the following criteria: -

1 . Investment costs.

2 . Total employment.

Where investment costs occupy the first place for the food industry, while labor takes second place as the food industry is one of the most important areas affected by the global variables.

\section{REVIEW OF LITERATURE}

Diane (2009) provides a provocative look at how CTM theory and practice are superseded by the creativity, flexibility, and innovation of day-to-day entrepreneurship. The paper validates a framework for the analysis of marketing practices specific to entrepreneurs.

P. Yasanallah ,et al (2012) Studies the Status of Marketing Mix (7Ps) in Consumer Cooperatives at Province from Members' Perspectives. As a result, hypotheses on price, location, promotion, product, operation management and physical assets show lower than the average status of these elements were confirmed. The only hypothesis that was rejected was the hypothesis related to the personnel element. This shows the proper condition of this element of marketing mix.

Thomas (2010) results indicate that adaptation is greatest for distribution, followed by price, promotion, and product. Product adaptation is influenced by market factors, price adaptation is influenced by market and industry factors, promotion adaptation is influenced by market factors, and distribution adaptation is influenced by company factors. The results of the research can be used to both understand and manage the extent of adaptation necessary for products in international markets.

Gandolfo, et al. (2009) The objective is to extract and synthesize 'best evidence' regarding marketing mix standardization practices in multinational corporations and to identify evidence regarding the performance impact of marketing mix standardization. this review is useful for management practitioners in multinationals seeking to integrate operations across borders. findings of a systematic review of the literature on marketing mix standardization in multinational corporations.

Carl Arthur (2000) Study mentioned that the standardization versus customization issue in international marketing has important organizational aspects that are often neglected in the literature.

Chan S. Yeua,et al (2012) study focused on the 4P approach of marketing mix which is based on product, price, promotion and places analysis. McDonald's marketing strategy in China and India were used for this study. The study found that the McDonald's has adopted a different kind of its $4 \mathrm{P}$ in their international marketing mix based on both, localization and globalization approaches. 
Frank Germann (2013) analysis reveals important moderators: more intense industry competition and more rapidly changing customer preferences increase the positive impact of the deployment of marketing analytics on firm performance.

Recep (2012)study has supposed to assist marketers in their efforts to behave in an ethical fashion. It is assumed that local conditions of markets may be different, but some global markets, ethics, and social responsibility principles should be applicable to all markets

Craig (2005)findings indicate that export venture management characteristics and adapting to foreign market needs as barriers to export were the significant predictors of export marketing performance.

\subsection{Research Question}

What is the relationship between Environmental Variables and marketing Mix?

\section{STATISTICAL ANALYSIS}

The study aims to examine Challenges to multinational companies and its impact on the marketing policies such as Production, Pricing, Distribution, and Promotion. To achieve the goal,

The researcher took a sample participants of 110 managers and specialists from the studied companies and gave them a questionnaire about Challenges to multinational companies and its impact on the marketing policies, their response to the questionnaire is shown in table (2) The questionnaire responses:

And to know the impact of the Egyptian revolution and Challenges to multinational companies and its impact on the marketing policies, the researcher is trying to test the following hypotheses of the study by Theses Variables:

Instability of Government regulations

Instability of political environment

Economic fluctuations

Lack of security and stability

\section{A. Hypotheses:}

A.1, There is no statistically significant relationship between Instability of Government regulations and marketing policies.

A.2, There is no statistically significant relationship between Instability of political environment and marketing policies.

A.3, There is no statistically significant relationship between Economic fluctuations and marketing policies.

A.4, There is no statistically significant relationship between Lack of security and stability and marketing policies. 


\section{B. Data Analysis}

After encoding and unloading and entering data for the computer, the researcher used the nineteenth version of the statistical program: Statistical package for social science (SPSS) to conduct statistical analysis of the study data as follows:

\section{B.1. Hypothesis " 1 " testing:}

There is no statistically significant relationship between Instability of Government regulations and marketing policies.

The researcher has to verify this hypothesis by studying the following: -

1- Simple linear regression model to study the effect of Instability of Government regulations ( the independent variable), and marketing policies in multinational companies ( dependent variable )

Measuring the impact of the independent variable on the dependent variable using simple regression:

The analysis of the simple linear regression refers to the relationship linear form between the independent variable and the dependent variable, and the proportion of the impact of the independent variable Instability of Government regulations on the dependent variable marketing production policies. The SPSS program helps in determining the level of significance of P-value as shown in table (3) The regression relationship between the Instability of Government regulations and the marketing production policies. From the table we could conclude that :

The significance of the estimated regression model where the F- value is (933.39) for the regression model of the dependent variable on the independent variable at significance level (0.00).

The regression coefficient signal is positive for the independent variable, it means that the relationship between the independent variable and the dependent variable is a direct correlation, in the sense that the increase in the independent variable leads to an increase in the dependent variable.

The increasing of the intermediate variables which are related to Instability of Government regulations by one unit leads to an extrusive change in achieving the cultural adaptation by (0.588) unit approx.

The level of significance of $\mathrm{T}$-test for the independent variable with the dependent variable is (0.00), which is less than the level of significance of 5\%, and this proves the existence of a statistically significant relationship between Instability of Government regulations and marketing policies.

The coefficient of determination R2 Shows the percentage of interpretations that the independent variable can interpret for the changes that affect achieving marketing polices (0.661). Regression model can be formulated for the independent variable (Government regulations and marketing policies) as follows: - $\mathrm{Y}=19.17+0.588 \mathrm{X}$ 


\section{B.2. Hypothesis " 2 " testing:}

There is no statistically significant relationship between Instability of political environment and marketing policies.

The researcher has to verify this hypothesis by studying the following: -

1- Simple linear regression model to study the effect of Instability of political environment (the independent variable), and marketing policies in multinational companies ( dependent variable )

Measuring the impact of the independent variable on the dependent variable using simple regression:

The analysis of the simple linear regression refers to the relationship linear form between the independent variable and the dependent variable, and the proportion of the impact of the independent variable Instability of political environment on the dependent variable marketing policies. The SPSS program helps in determining the level of significance of P-value as shown in table (4) The regression relationship between the political environment and the marketing policies in multinational companies. From the table we could conclude that :

- The significance of the estimated regression model where the F- value is (640.52) for the regression model of the dependent variable on the independent variable at significance level (0.00)

- The regression coefficient signal is positive for the independent variable, it means that the relationship between the independent variable and the dependent variable is a direct correlation, in the sense that the increase in the independent variable leads to an increase in the dependent variable.

- The increasing of the intermediate variables which are related to Instability of political environment by one unit leads to an extrusive change in The marketing policies by 0.511 units approx.

The level of significance of T-test for the independent variable with the dependent variable is (0.00), which is less than the level of significance of $5 \%$, and this proves the existence of a statistically significant relationship between Instability of political environment and marketing policies.

- The coefficient of determination R2 Shows the percentage of interpretations that the independent variable can interpret for the changes that affect marketing policies (0.661).

- Regression model can be formulated for the independent variable (Instability of political environment ) as follows: - $\quad \mathrm{Y}=22.68+0.511 \mathrm{X}^{\wedge} 2$

\section{B.3. Hypothesis " 3 " testing:}

There is no statistically significant relationship between Economic fluctuations and marketing policies.

The researcher has to verify this hypothesis by studying the following: -

1- Simple linear regression model to study the effect of Economic fluctuations (the independent variable), and marketing policies in multinational companies (dependent variable) 
Measuring the impact of the independent variable on the dependent variable using simple regression:

The analysis of the simple linear regression refers to the relationship linear form between the independent variable and the dependent variable, and the proportion of the impact of the independent variable Economic fluctuations on the dependent variable marketing policies. The SPSS program helps in determining the level of significance of $\mathrm{P}$-value as shown in Table (5) The regression relationship between the Economic fluctuations and the marketing policies in multinational companies . From the table we could conclude that:

- The significance of the estimated regression model where the F- value is (480.18) for the regression model of the dependent variable on the independent variable at significance level $(0.00)$

- The regression coefficient signal is positive for the independent variable, it means that the relationship between the independent variable and the dependent variable is a direct correlation, in the sense that the increase in the independent variable leads to an increase in the dependent variable.

- The increasing of the intermediate variables which are related to Economic fluctuations by one unit leads to an extrusive change in The marketing policies by 0.774 units approx.

- The level of significance of T-test for the independent variable with the dependent variable is (0.00), which is less than the level of significance of $5 \%$, and this proves the existence of a statistically significant relationship between Economic fluctuations and marketing policies.

- The coefficient of determination R2 shows the percentage of interpretations that the independent variable can interpret for the changes that affect Marketing policies (0.501).

- Regression model can be formulated for the independent variable (Economic fluctuations) as follows:- $\quad \mathrm{Y}=24.86+0.774 \mathrm{X}^{\wedge} 3$

\section{B.4. Hypothesis "4" testing:}

There is no statistically significant relationship between Lack of security and stability and marketing policies.

The researcher has to verify this hypothesis by studying the following: -

1- Simple linear regression model to study the effect of Lack of security and stability ( the independent variable), and marketing policies in multinational companies ( dependent variable ) regression:

Measuring the impact of the independent variable on the dependent variable using simple

The analysis of the simple linear regression refers to the relationship linear between the independent variable and the dependent variable, and the proportion of the impact of the independent variable Lack of security and stability on the dependent variable marketing policies. 
The SPSS program helps in determining the level of significance of P-value as shown in Table (6) The regression relationship between the Lack of security and stability and the marketing policies in multinational companies. From the table we could conclude that :

Through the above table, it can be concluded that:

The significance of the estimated regression model where the F- value is (420.16) for the regression model of the dependent variable on the independent variable at significance level $(0.00)$

- The regression coefficient signal is positive for the independent variable, it means that the relationship between the independent variable and the dependent variable is a direct correlation, in the sense that the increase in the independent variable leads to an increase in the dependent variable.

- The increasing of the intermediate variables which are related to Lack of security and stability by one unit leads to an extrusive change in The marketing policies by 0.654 units approx.

- The level of significance of T-test for the independent variable with the dependent variable is $(0.00)$, which is less than the level of significance of $5 \%$, and this proves the existence of a statistically significant relationship between Lack of security and stability and marketing policies.

- The coefficient of determination R2 shows the percentage of interpretations that the independent variable can interpret for the changes that affect promotion policies (0.664).

- Regression model can be formulated for the independent variable (Lack of security and stability) as follows:- $\mathrm{Y}=24.86+0.654 \mathrm{X}^{\wedge} 3$

\section{RESULTS}

Within the theoretical framework of the study and in the light of the results of the field study of marketing policies of multinational companies in the Arab Republic of Egypt and its role in the local, regional and global challenges, the analysis of data and testing hypotheses of the study, the overall results of the research could be determined as follows:

A. There is a significantly positive statistical relationship between Instability of Government regulations and Marketing policies in multinational companies; where the results of the analysis show the following:

A.1, There is a correlation between the independent variable (Instability of Government regulations) and the dependent variable (Marketing policies) because the level of significance is less than $5 \%$ and this indicates the presence of correlation between the dependent variable and the independent variable.

A.2, There is a direct correlation (positive) between the independent variable and the dependent variable where the signal of the correlation coefficient is positive, and this means that there is a positive relationship.

A.3, Signals of the regression coefficient are positive for the independent variable, which means that the relationship between the independent and dependent variables is positive; which 
means that the increasing of the independent variable leads to increasing of the dependent variable.

B. There is a significantly positive statistical relationship between Instability of political environment and Marketing policies in multinational companies; where the results of the analysis show the following:

B.1, There is a correlation between the independent variable (Instability of political environment) and the dependent variable (Marketing policies) because the level of significance is less than $5 \%$ and this indicates the presence of correlation between the dependent variable and the independent variable.

B.2, There is a direct correlation (positive) between the independent variable and the dependent variable where the signal of the correlation coefficient is positive, and this means that there is a positive relationship.

B.3, Signals of the regression coefficient are positive for the independent variable, which means that the relationship between the independent and dependent variables is positive; which means that the increasing of the independent variable leads to increasing of the dependent variable.

C. There is a significantly positive statistical relationship between Economic fluctuations and Marketing policies in multinational companies; where the results of the analysis show the following:

C.1, There is a correlation between the independent variable (Economic fluctuations

) and the dependent variable (Marketing policies)because the level of significance is less than $5 \%$ and this indicates the presence of correlation between the dependent variable and the independent variable.

C.2, There is a direct correlation (positive) between the independent variable and the dependent variable where the signal of the correlation coefficient is positive, and this means that there is a positive relationship.

C.3, Signals of the regression coefficient are positive for the independent variable, which means that the relationship between the independent and dependent variables is positive; which means that the increasing of the independent variable leads to increasing of the dependent variable.

D. There is a significantly positive statistical relationship between Lack of security and stability and Marketing policies in multinational companies; where the results of the analysis show the following:

D.1, There is a correlation between the independent variable (Lack of security and stability) and the dependent variable (Marketing policies) because the level of significance is less than $5 \%$ and this indicates the presence of correlation between the dependent variable and the independent variable. 
D.2, There is a direct correlation (positive) between the independent variable and the dependent variable where the signal of the correlation coefficient is positive, and this means that there is a positive relationship.

D.3, Signals of the regression coefficient are positive for the independent variable, which means that the relationship between the independent and dependent variables is positive; which means that the increasing of the independent variable leads to increasing of the dependent variable.

\section{CONCLUSION}

This paper focuses on the impact of Challenges to multinational companies on the marketing policies in multinational companies by using the Egyptian data and testing on it. The main objective of the study is first to investigate if there is any coordination between Challenges to multinational companies and the marketing policies in multinational companies. It was found that Challenges to multinational companies had an effect on the marketing policies. Furthermore, the estimation results proved the validity of the Hypotheses as it was found a positive and statistically significant relationship between Challenges to multinational companies. Challenges to multinational companies made a lot of problems that had its effect on the marketing policies in multinational companies:

- Unemployment remains high. Corruption and cronyism continue as factors in the Egyptian economy's inability to create jobs and the prevalence of informality and social exclusion.

- A major obstacle to this has long been corruption and cronyism.

- The Egyptian private sector and Multinational Companies Have been dominated by a relatively small number of large firms that enjoy privileged positions and are able to employ monopolistic practices to generate easy profits.

- The Egyptian armed forces themselves continue to own and operate many factories and businesses unrelated to military needs. Taken together, this means the armed forces control much of the economy.

- Increasing taxes

- The economy is suffering From the lack of tourists some sectors make little to nothing

- Prices are exploding

- Egypt suffered from corruption and bad economic performance 


\section{REFERENCES}

Blumentritt T., P., \& Nigh, D., (first quarter, 2002) "The Integration of Subsidiary Political Activities in Multinational Corporations," Journal of International Business Studies.

Cavusgil, S. T., Knight, G., \& Riesenberger, J. R. (2008). International business: Strategy, management, and the new realities. Upper Saddle River, NJ: Pearson Prentice-Hall.

Central Agency for Public Mobilization And Statistics (CAMPAS), 2011. Available at: http://www.campas.gove.eg

Chan, S. Y. , Kong C. L. , \& Lee C. T. , (December 2012). A Comparative Study on International Marketing Mix in China and India: The Case of McDonald's, International Congress on Interdisciplinary Business and Social Sciences, Vol 65.

Chesbrough, H., \& Crowther, A.K., (2006). Beyond high tech: early adopters of open innovation in other industries . R\&D Management. Vol 36 (3), 229-236.

Chesbrough, H., (2003). Open Innovation: The New Imperative for Creating and Profiting from Technology. Harvard Business School Press, Boston, MA.

Clougherty, J., A., (third quarter, 2001) "Globalization and the Autonomy of Domestic Competition Policy: An Empirical Test on the World Airline Industry,” Journal of International Business Studies Vol 32.

Craig, C. J. (2005) The impact of barriers to export on export marketing performance', Journal of Global Marketing.

Croft, S., L., \& Tourdonnet, B., H., (February 2000). France and England: The European Product Liability Directive in Practice," For the Defense

Diane, M. M., (2009). The entrepreneurial marketing mix, Qualitative Market Research: An International Journal, Vol. 12.

Digital Microwave Corporation (2000) Annual Report, 20-1.

Dominici, G., Birnik, A., \& Bowman, C., (2009). From Marketing Mix to e-Marketing Mix: a literature overview and classification, International Journal of Business and Management, Vol 4.

Donnel A. B., Michael W. M., \& Simonson, I.,(2000). Reasons as Carriers of Culture: Dynamic versus Dispositional Models of Cultural Influence on Decision Making. Journal of Consumer Research. Vol 27

Freedom in the World (2002): Freedom Gains Despite Global Threats, Freedom House.

Freedom of the Press (2011): A Global Survey of Media Independence (Freedom House), www.freedomhouse. org/pfs 2011/pfs 2011.pdf.

German Court Rules Against Wal-Mart. (2002, November 13). San José Mercury News,.

Germann, F., Gary L. L., \& Rangaswamy, A.,( 2013) Performance implications of deploying marketing analytics, International Journal of Research in Marketing.

Gomez-Mejia, L. R., Balkin, D. B. \&Cardy, R. L. (2001). Managing Human Resources (3rd ed). Upper Saddle River, NJ: Prentice Hall

http://www.ciibroadcasting.com/2013/09/17/egypt-coup-government-recognises-morsis-economic-achieve ments/

http://www.middleeastmonitor.com/news/africa/7379-egypts-interim-government-recognises-morsis-economicachievements\#s thash.NTHSmcU8.dpuf

India Honors Bride Who Fought Dowry. (2003, May 17). San José Mercury News,.

Jacobs, D., Waalkens, J., (2001). (Innovation Squared: Innovation in the Organization of Innovation). AWT Achtergrondstudie, vol. 23. Kluwer, Deventer.

Jobber, D., (2004) Principles and practice of marketing, 4th edition, the McGraw-Hill Companies 
Kay, J., (2001) “A Poor View of Poverty,” Financial Times.

Keupp, M., M., Gassmann,O., (2009). Research in International Business and Finance.Opening Up to Capital Flows? Be Prepared Before Plunging in,. IMF Survey, May 19, 2003, 137.

Luo, Y., (third quarter, 2001) "Toward a Cooperative View of MNC-Host Governments Relations: Building Blocks and Performance Implications,” Journal of International Business Studies,. Vol 32.

NAFTA's Scoreboard: So Far, So Good. (2001, July 9). Business Week,. 54-5.

Offsetting the Costs of Employment Protection?. (2003, June 30 ( IMF Survey.197-8.

Onkvisit, S., \& Shaw, J., ( 2004) International Marketing Analysis and strategy, Fourth edition.

Petras, J., (2004) The Power of Israel in the United States, Clarity Press, Atlanta, GA.

Powers, T., L., Loyka, J., J, (2010 ). Adaptation of Marketing Mix Elements in International Markets, Journal of Global Marketing. Vol 23

Roberts, H., J., Kayande,U., \& Stremersch, S.,( 2013) " From academic research to marketing practice: Exploring the marketing science value chain, Journal of Research in Marketing.

See the World, Erase Its Border.(2000, August 28). Business Week,.

Singapore Lets Its Hair Down. (2003, July 15). International Herald Tribune,.

Solberg, C. A. (2000). Standardization or Adaptation of the International Marketing Mix: The Role of the Local Subsidiary/Representative. Journal of International Marketing: Vol. 8, No. 1

The Central bank of Egypt. 2015. Annual report. Available at : www.cbe.org.eg.

Yasanallah, P., \& Bidram, V., (2012)"Studying the Status of Marketing Mix (7Ps) in Consumer Cooperatives at Ilam Province from Members' Perspectives," American Journal of Industrial and Business Management, Vol. 2.

YÜCEL, R., (2010) Globalization of markets, marketing ethics and social responsibility, Dissertation. 
Figure 1: Environmental Analysis Framework (EAF)

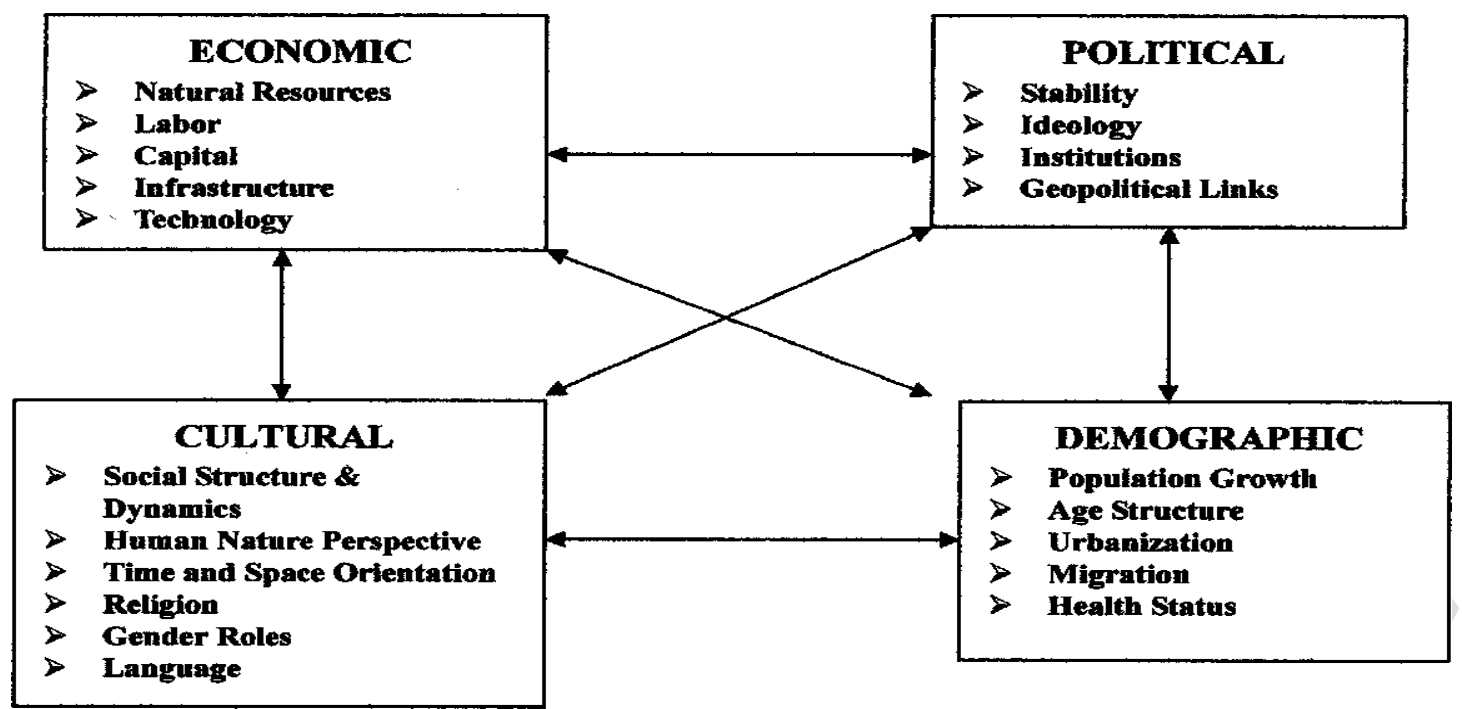

Source: Austin, James E. (1990). Managing in Developing Countries: Strategic Analysis and Operating Techniques.

Figure 2: The Marketing Environment

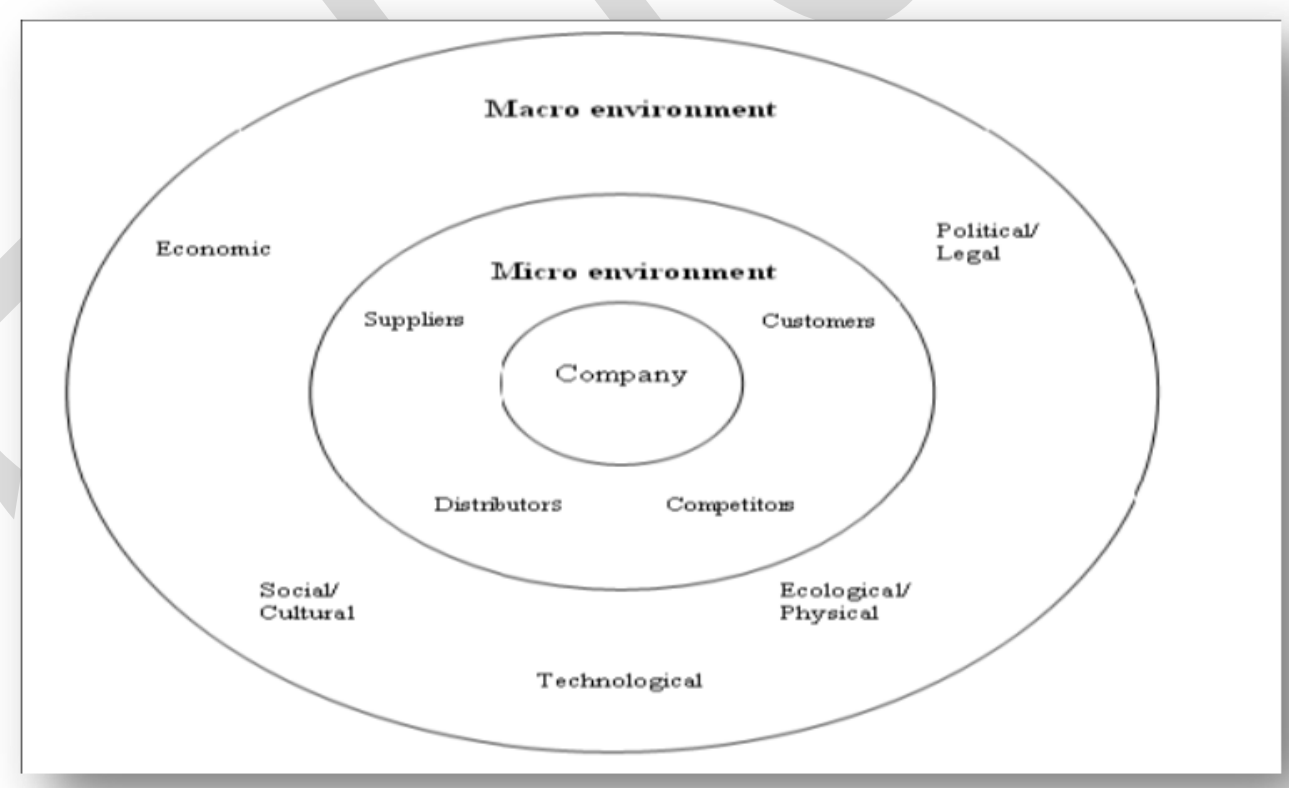

Source: (Jobber 2004: 133) 
Table 1: Distribution Of Multinational Industrial Companies According To The Type Of Industry

\begin{tabular}{|c|c|c|c|c|c|c|}
\hline \multirow{2}{*}{ Fields } & \multirow{2}{*}{$\begin{array}{c}\text { Investment } \\
\text { Costs }\end{array}$} & \multicolumn{2}{|c|}{ Issued Capital } & \multicolumn{2}{c|}{ Companies } & $\begin{array}{c}\text { Total } \\
\text { Employment }\end{array}$ \\
\cline { 3 - 7 } & & Percentage & $\begin{array}{c}\text { The Amount } \\
\text { In Million }\end{array}$ & Percentage & Number & \\
\hline $\begin{array}{c}\text { Engineering } \\
\text { Industries }\end{array}$ & 2103 & 17.6 & 1281 & 36.6 & 64 & 11324 \\
\hline $\begin{array}{c}\text { Chemical } \\
\text { Industries }\end{array}$ & 1799 & 20.9 & 1527 & 20.0 & 35 & 5356 \\
\hline $\begin{array}{c}\text { The food } \\
\text { industry }\end{array}$ & 2782 & 20.4 & 1489 & 13.1 & 23 & 5661 \\
\hline Metal industries & 1755 & 21.3 & 1553 & 10.9 & 19 & 5316 \\
\hline $\begin{array}{c}\text { The } \\
\text { pharmaceutical } \\
\text { industry }\end{array}$ & 1263 & 7.8 & 571 & 10.3 & 18 & 3479 \\
\hline $\begin{array}{c}\text { The textile } \\
\text { industry }\end{array}$ & 515 & 4.0 & 291 & 5.7 & 10 & 4627 \\
\hline Building materials & 1202 & 8.0 & 581 & 3.4 & 6 & 917 \\
\hline Total & 11419 & $\% 100$ & 7293 & 100 & 175 & 36680 \\
\hline
\end{tabular}

Source: General Authority for Investment and Free Zones, Annual Report 2012, p 66. 
Table 2: The Questionnaire Responses

\begin{tabular}{|l|c|c|c|c|c|}
\hline \multicolumn{1}{|c|}{ Phrase } & $\begin{array}{c}\text { Agree } \\
\text { Completely }\end{array}$ & Agree & Neutral & $\begin{array}{c}\text { Don't } \\
\text { Agree }\end{array}$ & $\begin{array}{c}\text { Don't Agree } \\
\text { Completely }\end{array}$ \\
\hline Free access to information & 20 & 10 & 10 & 25 & 35 \\
\hline Fighting corruption and eliminate it & 18 & 14 & 13 & 20 & 35 \\
\hline Press and media freedom & 10 & 6 & 4 & 70 & 20 \\
\hline Increasing investment opportunities & 15 & 5 & 8 & 18 & 54 \\
\hline Open new relations with neighboring countries & 21 & 9 & 17 & 23 & 30 \\
\hline Preventing monopolistic practices & 17 & 4 & 14 & 29 & 35 \\
\hline $\begin{array}{l}\text { Facilitating the movement of exports and imports and } \\
\text { removing all obstacles }\end{array}$ & 14 & 38 & 20 & 10 & 8 \\
\hline $\begin{array}{l}\text { Amendments taxes to be in favor of the investor and the } \\
\text { consumer }\end{array}$ & 22 & 8 & 27 & 12 & 30 \\
\hline Reduction of customs duties & 14 & 9 & 21 & 35 & 20 \\
\hline Encouraging economic openness & 13 & 9 & 19 & 22 & 36 \\
\hline Using electronic Trade and Marketing & 9 & 7 & 18 & 26 & 40 \\
\hline Accessing to regional and global markets & 7 & 5 & 15 & & 40 \\
\hline Reducing costs and use flexible pricing & 5 & 12 & 31 & 33 & 17 \\
\hline Development of methods and new channels of distribution & 21 & 33 & 19 & 17 & 13 \\
\hline Using interactive promotional methods with customers & 18 & 29 & 13 & 19 & 14 \\
\hline $\begin{array}{l}\text { To achieve a competitive advantage and a strategic position in } \\
\text { the market by strengthening the elements of production and } \\
\text { access to the overall quality of the product }\end{array}$ & 16 & 20 & 20 & 28 & 12 \\
\hline
\end{tabular}

Table 3. The Regression Relationship Between The Instability Of Government Regulations And The Marketing Production Policies

\begin{tabular}{|l|c|c|c|c|c|c|}
\hline \multicolumn{1}{|c|}{ Independent variable } & $\begin{array}{c}\text { Regression } \\
\text { coefficient }\end{array}$ & T Value & significance & $\begin{array}{c}\text { Coefficient of } \\
\text { determination } \\
\text { R2 }\end{array}$ & F Value & significance \\
\cline { 1 - 4 } Constant & $\mathbf{1 9 . 1 7}$ & $\mathbf{1 9 . 5 2}$ & $\mathbf{0 . 0 0}$ & $\mathbf{0 . 6 6 1}$ & $\mathbf{9 3 3 . 3 9}$ & $\mathbf{0 . 0 0}$ \\
\cline { 1 - 5 } $\begin{array}{l}\text { Instability of Government } \\
\text { regulations }\end{array}$ & $\mathbf{0 . 5 8 8}$ & $\mathbf{3 0 . 5 5}$ & $\mathbf{0 . 0 0}$ & & \\
\hline
\end{tabular}

Table 4. The Regression Relationship Between The Political Environment And The Marketing Policies In Multinational Companies.

\begin{tabular}{|c|c|c|c|c|c|c|}
\hline Independent variable & $\begin{array}{l}\text { Regression } \\
\text { coefficient }\end{array}$ & Value $\mathrm{T}$ & significance & $\begin{array}{l}\text { Coefficient of } \\
\text { determination }\end{array}$ & Value $\mathrm{F}$ & significance \\
\hline Constant & 22.68 & 21.67 & 0.00 & \multirow[b]{2}{*}{0.572} & \multirow[b]{2}{*}{640.52} & \multirow[b]{2}{*}{0.00} \\
\hline $\begin{array}{c}\text { Instability of political } \\
\text { environment }\end{array}$ & 0.511 & 25.31 & 0.00 & & & \\
\hline
\end{tabular}


Table 5. The Regression Relationship Between The Economic Fluctuations And The Marketing Policies In Multinational Companies

\begin{tabular}{|c|c|c|c|c|c|c|}
\hline Independent variable & $\begin{array}{c}\text { Regression } \\
\text { coefficient }\end{array}$ & Value T & significance & $\begin{array}{c}\text { Coefficient of } \\
\text { determinationR2 }\end{array}$ & Value F & significance \\
\hline Constant & $\mathbf{2 4 . 6 8}$ & $\mathbf{2 2 . 0 9}$ & $\mathbf{0 . 0 0}$ & $\mathbf{0 . 5 0 1}$ & $\mathbf{4 8 0 . 1 8}$ & $\mathbf{0 . 0 0}$ \\
\cline { 1 - 5 } Economic fluctuations & $\mathbf{0 . 7 7 4}$ & $\mathbf{2 1 . 9 1}$ & $\mathbf{0 . 0 0}$ & & \\
\hline
\end{tabular}

Table 6. The Regression Relationship Between The Lack Of Security And Stability And The Marketing Policies In Multinational Companies

\begin{tabular}{|l|c|c|c|c|c|c|}
\hline \multicolumn{1}{|c|}{ Independent variable } & $\begin{array}{c}\text { Regression } \\
\text { coefficient }\end{array}$ & $\begin{array}{c}\text { Value } \\
\mathrm{T}\end{array}$ & significance & $\begin{array}{c}\text { Coefficient of } \\
\text { determinationR2 }\end{array}$ & Value F & Significance \\
\hline Constant & $\mathbf{2 0 . 1 8}$ & $\mathbf{1 9 . 0 9}$ & $\mathbf{0 . 0 0}$ & $\mathbf{0 . 6 6 4}$ & $\mathbf{4 2 0 . 1 6}$ & $\mathbf{0 . 0 0}$ \\
\hline $\begin{array}{l}\text { Lack of security and } \\
\text { stability }\end{array}$ & $\mathbf{0 . 6 5 4}$ & $\mathbf{2 0 . 9 1}$ & $\mathbf{0 . 0 0}$ & & \\
\hline
\end{tabular}

